\title{
ANALISA PERILAKU SAMBUNGAN BALOK-KOLOM SESUAI PBI 1971 TERHADAP BEBAN SIKLIK
}

\author{
Delfian Masrura $^{1)}$, Abdullah ${ }^{2)}$ \\ ${ }^{1)}$ Magister Teknik Sipil, Universitas Syiah Kuala, Banda Aceh 23111, Indonesia \\ ${ }^{2)}$ Jurusan Teknik Sipil, Universitas Syiah Kuala, Banda Aceh 23111, Indonesia \\ email:_delfianmasrura09@gmail.com ${ }^{1)}$,email: abdullahmahmud@unsyiah.ac.id ${ }^{2)}$
}

DOI: http://dx.doi.org/10.29103/tj.v10i2.340

(Received: July 2020 / Revised: August 2020 / Accepted: August 2020)

\begin{abstract}
Abstrak
Kolom dan balok adalah komponen struktur utama yang berfungsi menyangga beban struktur lainnya untuk sebuah bangunan. Daerah pada sambungan (joint) balok-kolom harus didesain dengan akurat sehingga mampu menyebarkan energi yang diterima dengan baik pada saat terjadi gempa. Sebagai komponen struktur dengan peran dan fungsi tersebut, kolom dan balok menempati posisi penting dalam bangunan. Kemampuan joint balok kolom untuk berdeformasi terhadap beban siklik dapat memberikan struktur yang baik. Kegagalan joint balok-kolom berpengaruh langsung pada komponen struktur lain yang berhubungan dengannya. Tujuan dari penelitian ini adalah untuk mempelajari kemampuan struktur bangunan pada elemen joint balok kolom dalam menahan beban siklik sesuai dengan peraturan PBI 1971. Benda uji yang dibuat adalah benda uji dengan panjang penyaluran tulangan tidak berkait sesuai PBI 1971, dengan mutu beton 23,02 MPa. Balok berukuran 120 × 30 x $40 \mathrm{~cm}$ dan kolom berukuran $30 \times 30 \times 200 \mathrm{~cm}$ menggunakan tulangan $8 \varnothing 14 \mathrm{~mm}$ dengan tegangan leleh (fy) 310,03 MPa dan tulangan sengkang $\varnothing 10-100 \mathrm{~mm}$ dengan tegangan leleh $(f y)$ 374,59 MPa. Pengujian dilakukan dengan memberikan beban siklik di ujung balok dengan pembebanan 2,5 ton; 5 ton; 7,5 ton dan monotonik yaitu beban hingga benda uji hancur. Hasil yang dicapai pada penelitian ini adalah sambungan balok kolom yang berdasarkan PBI 1971 mampu menahan kapasitas beban siklik sampai dengan 7,47 tf untuk beban tekan dan 5,19 tf untuk beban tarik pada displacement $24 \mathrm{~mm}$.
\end{abstract}

Kata Kunci: Sambungan Balok-Kolom, PBI 1971, Beban Siklik.

\begin{abstract}
Columns and beams are the main structural components that serve to support the burden of other structures for a building. The beam-column area's must be designed accurately in order to be able to distribute the received energy properly when an earthquake occurs. Columns and beams occupy important positions in buildings as structural components with these roles and functions. The ability of column-beam joints to deform cyclic loads provides a good structure. The beam-column joint failure has a direct effect on other structural components associated with it. The purpose of this study was to study the ability of building structures on beam-column joint elements in holding cyclic loads in accordance with PBI 1971. The specimen was created with length of unbalanced reinforcement distribution in accordance with PBI 1971, with $23.02 \mathrm{MPa}$ of concrete quality. Beams measuring $120 \times 30 \times 40 \mathrm{~cm}$ and columns measuring $30 \times 30 \times 200 \mathrm{~cm}$ using reinforcement $8 \varnothing 14 \mathrm{~mm}$ with melting stress (fy) $310.03 \mathrm{MPa}$ and stirrup reinforcement $\varnothing 10-100 \mathrm{~mm}$ with melting stress (fy) $374.59 \mathrm{MPa}$. The test is carried out by giving cyclic load to the end of the beam with a load of $2.5 \mathrm{tf} ; 5.0 \mathrm{tf} ; 7.5 \mathrm{tf}$; and monotonic that is the load until the test object is
\end{abstract}


destroyed. The results achieved in this study as the specimen is able to hold the maximum load 7.47 tf to pressure loads and 5.19 tf to strain loads in the displacement of $24 \mathrm{~mm}$

Keywords: Joint Beam-Column, PBI 1971, Cyclic Load.

\section{Latar Belakang}

Indonesia berada pada zona tektonik yang aktif karena diapit oleh lempeng besar dunia dan interaksi antar lempeng ini menempatkan Indonesia sebagai wilayah yang rawan terhadap gempa. Gempa bumi sering merusak infrastruktur. Usaha untuk mengurangi dampak kerusakan akibat gempa bumi dapat dilakukan dengan perencanaan yang tahan gempa. Salah satu kerusakan yang umum terjadi pada konstruksi adalah pada sambungan (joint) balok-kolom. Joint balok-kolom merupakan komponen struktur utama yang berfungsi menyangga beban struktur lainnya. Perencanaan struktur yang baik pada daerah joint balok-kolom dapat memberikan kekuatan geser yang lebih tinggi. Mutu beton dan tulangan baja yang dipakai dalam penelitian ini juga merupakan variabel penting dalam menentukan kapasitas dari joint balok-kolom.

Balok adalah elemen struktural yang menerima gaya-gaya yang bekerja dalam arah tranversal terhadap sumbunya yang mengakibatkan terjadinya momen lentur dan gaya geser sepanjang bentangnya (Dipohusodo, 1994). Sedangkan, kolom merupakan suatu elemen struktur tekan yang memegang peranan penting dari suatu bangunan, sehingga keruntuhan pada suatu kolom merupakan lokasi kritis yang dapat menyebabkan runtuhnya lantai yang bersangkutan dan runtuh total seluruh struktur (Sudarmoko, 1996). Benda uji balok-kolom yang digunakan pada penelitian kali ini adalah beton bertulang. (Nawy, 1998) menyatakan bahwa keruntuhan beton bertulang dibagi tiga ragam keruntuhan yaitu keruntuhan lentur, keruntuhan tarik diagonal, dan keruntuhan tekan geser. Berdasarkan (PBI 1971, 1971) salah satu metode perencanaan desainnya adalah dengan menggunakan metode perencanaan beban kerja. Perencanaan tersebut akan menghasilkan beton bertulang dengan kondisi yang diharapkan yaitu lendutan yang terjadi masih dalam batas yang diijinkan dan retakan yang timbul masih dapat dikendalikan.

Adapun tujuan dari penelitian ini adalah untuk mengetahui kapasitas beban maksimum yang mampu ditahan oleh benda uji yang sesuai dengan PBI 1971, karena sampai saat ini masih terdapat banyak bangunan lama yang sudah dibangun dan masih berdiri, yang direncanakan konstruksi bangunannya menggunakan standar PBI 1971. Sehingga, hasil dari penelitian ini diharapkan dapat menjadi representasi terhadap konstruksi pada bangunan yang lama yang sudah berdiri dan hasil tersebut juga dapat menjadi salah satu solusi dan referensi penyusunan regulasi untuk perencanaan konstruksi dalam menangani kegagalan struktur yang terjadi pada daerah sambungan (joint) balok dan kolom.

\section{Metode Penelitian}

\subsection{Parameter Kinerja Struktur Perilaku Sambungan Balok Kolom}

Pengujian struktur terhadap beban lateral siklik menghasilkan suatu kurva histeritik. Perilaku struktur terhadap beban siklik diperlihatkan pada Gambar 1 . Berdasarkan kurva tersebut, dapat diketahui bahwa parameter kinerja struktur 
perilaku sambungan balok kolom akibat beban lateral siklik diantaranya adalah kapasitas kekuatan puncak, penurunan kekakuan, energi disipasi dan daktilitas.

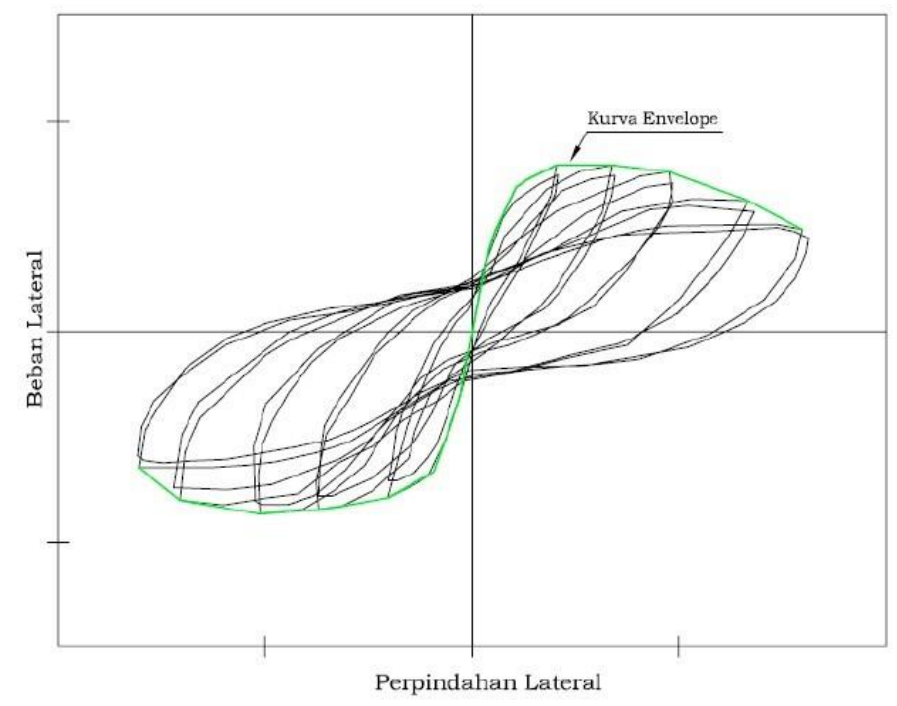

Gambar 1 Tipikal kurva histeritik perilaku struktur terhadap beban siklik

Kekakuan benda uji pada suatu siklus pembebanan didefinisikan sebagai kemiringan garis yang menghubungkan titik puncak tarik dan titik puncak tekan pada siklus tersebut atau lebih dikenal dengan kekakuan secant. Penurunan kekakuan secant pada benda uji balok kolom dapat dihitung dengan menggunakan rumus. Menurut (Timoshenko, 1986), definisi kekakuan sebagai gaya yang dibutuhkan untuk menghasilkan suatu lendutan sebesar satu satuan, seperti yang ditunjukkan pada:

$$
k=\frac{P}{\delta}
$$

\section{Keterangan}

$$
\begin{aligned}
& k=\operatorname{Kekakuan}(\mathrm{N} / \mathrm{mm}) \\
& P=\operatorname{Beban}(\mathrm{N}) \\
& \delta=\operatorname{Lendutan}(\mathrm{mm})
\end{aligned}
$$

Energi total yang diberikan kepada struktur pada suatu pembebanan disebut energi input. Sebagian energi input yang diberikan pada struktur diserap (didisipasi) oleh struktur melalui mekanisme kerusakan berupa keretakan struktur dan kelelehan tulangan.Energi disipasi dapat dihitung dengan persamaan:

$$
E i=E e+E d
$$

Keterangan

$$
\begin{aligned}
& E i=\text { energi input total } \\
& E e=\text { energi elastis } \\
& E d=\text { energi disipasi }
\end{aligned}
$$


Daktilitas struktur didefenisikan sebagai kemampuan struktur untuk mengalami deformasi inelastis tanpa mengalami kehilangan kekakuan yang signifikan. Secara umum daktilitas dinyatakan sebagai perbandingan antara perpindahan ultimit dan perpindahan leleh. Perpindahan ultimit ditentukan dari perpindahan saat kekuatan puncak telah turun sebesar 20\% kekuatan maksimum. Daktilitas struktur dapat ditentukan melalui persamaan:

$$
\mu=\frac{d_{u}}{d_{y}}
$$

Keterangan

$$
\begin{aligned}
& \mu=\text { Daktilitas } \\
& d_{u}=\text { Perpindahan ultimit }(\mathrm{mm}) \\
& d_{y}=\text { Perpindahan leleh }(\mathrm{mm})
\end{aligned}
$$

\subsection{Objek Penelitian}

Benda uji yang digunakan pada penelitian ini adalah beton bertulang balok dan kolom, yang dibuat sesuai PBI 1971 dengan balok berukuran 30x120x40 cm dan kolom berukuran 30x30x200 $\mathrm{cm}^{3}$ serta mengunakan tulangan $8 \varnothing 14 \mathrm{~mm}$ dan tulangan sengkang Ø10-100 mm dan dilakukan pengujian pada umur 28 hari.

Tulangan utama yang digunakan adalah $8 \varnothing 14 \mathrm{~mm}$ dan tulangan sengkang menggunakan baja $\varnothing 10-100 \mathrm{~mm}$. Disiapkan juga benda uji trial berbentuk silinder ukuran 15 × $30 \mathrm{~cm}$. Benda uji dibuat untuk pengujian kapasitas beban siklik pada joint balok kolom beton bertulang, terdiri dari agregat halus, agregat kasar, besi tulangan dan air. Pada penelitian ini, benda uji beton bertulang akan mengunakan agregat normal seperti kerikil, pasir, dan air.

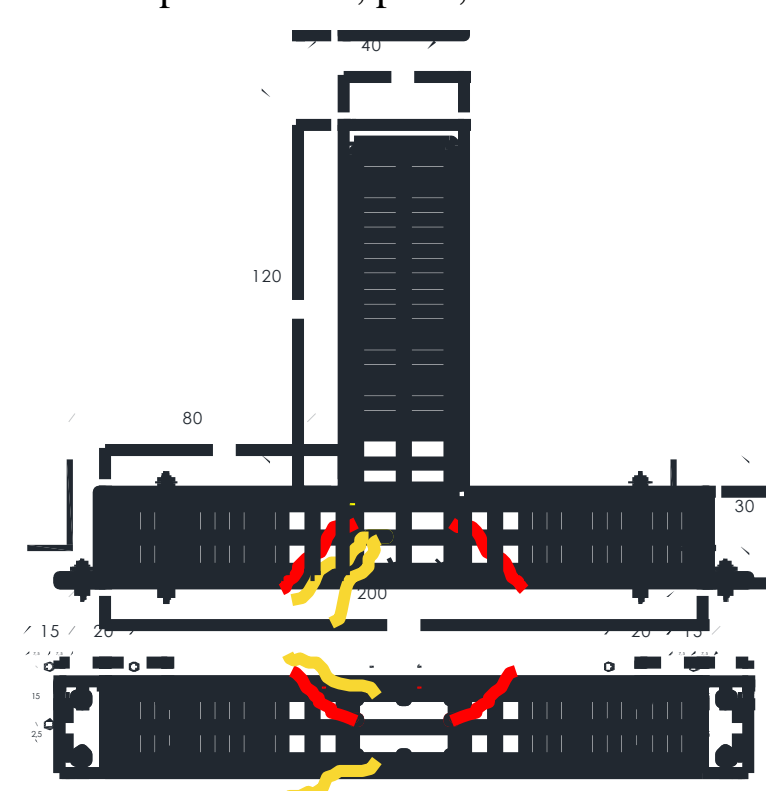

Gambar 2. Detail penulangan pada benda uji PBI 1971

Lebih jelas bentuk dan detail benda uji joint balok kolom dapat dilihat pada gambar di bawah ini. Strain gaige baja dipasang pada tulangan tulangan utama daerah joint balok kolom, seperti diperlihatkan pada Gambar 2. 


\subsection{Prosedur Pengujian}

Pengujian dilakukan setelah umur beton mencapai 28 hari, dengan benda uji dipasang secara kaku pada rangka baja (frame) yang tersedia. Sebelum dilakukan pengujian, permukaan benda uji di cat warna putih dan digambar grid terlebih dahulu, agar memudahkan dalam menggambar pola retak yang dihasilkan. Pada permukaan ujung bidang balok dipasangkan plat baja dua arah, yang dihubungkan dengan baut, kemudian plat diikat ke load cell dan diberikan beban siklik. Pada sisi balok dipasang transducer untuk membaca defleksi arah lateral.

Beban diberikan horizontal terhadap ujung balok. Beban horizontal diberikan oleh dongkrak hidran (hydraulic jack) yang terhubung dengan load cell dan diteruskan ke benda uji balok kolom. Beban yang diberikan dikontrol dengan membaca dial pada data logger. Perbebanan dilakukan secara siklik dan digambarkan pola retaknya. Beban diberikan hingga benda uji hancur.

Regangan yang terjadi pada joint balok kolom dibaca oleh Portable Data Logger yang telah dihubungkan pada strain gauge. Pembebanan dihentikan pada saat beban tidak lagi meningkat akibat benda uji tidak mampu menerima beban sehingga benda uji mengalami retak dan hancur. Pola perkembangan retak dimonitor pada setiap saat dengan membuat gambar retak yang terjadi pada kolom sesuai dengan besar beban yang diberikan.

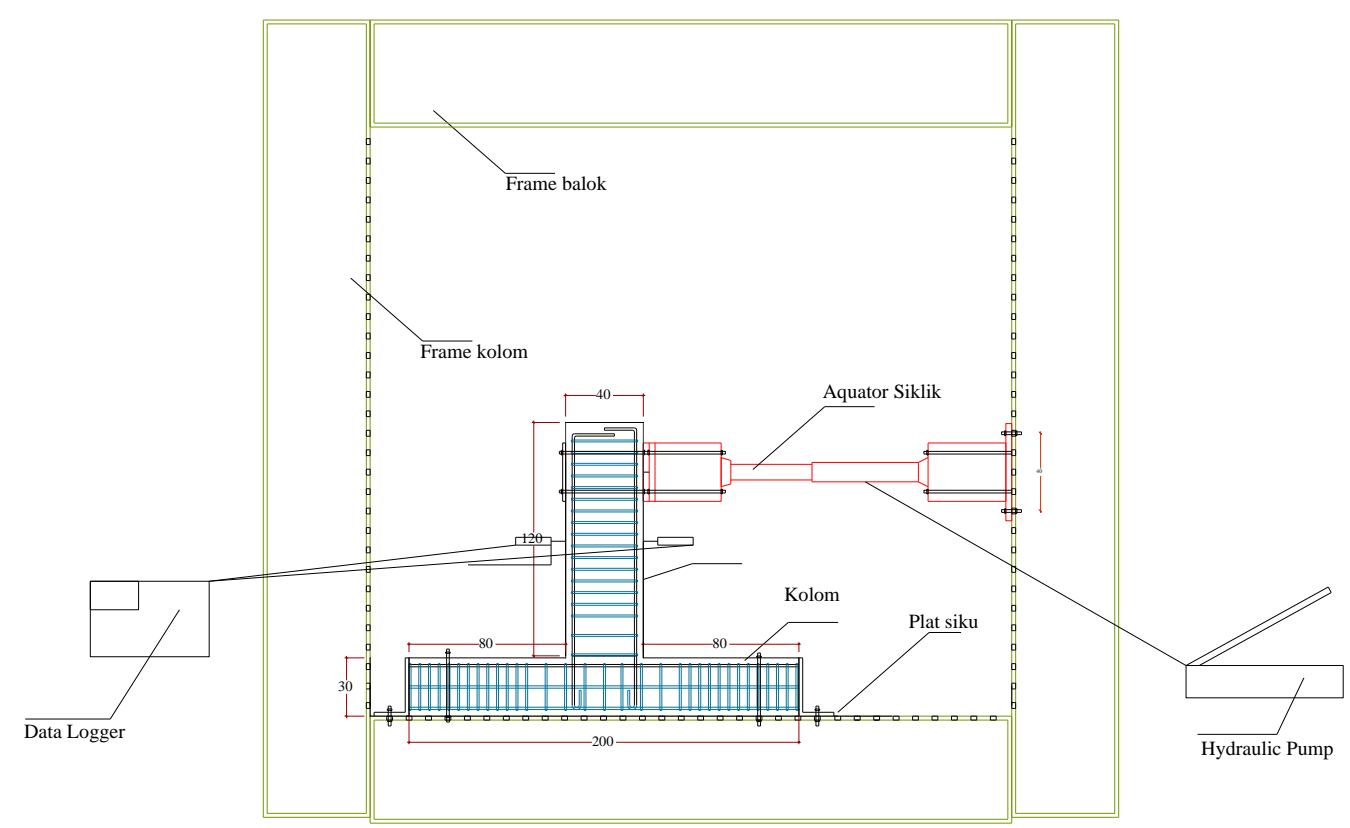

Gambar 3. Set up benda uji balok kolom

Beban yang diberikan terhadap benda uji adalah beban siklik, yang diasumsikan sebagai beban gempa bumi. Pemberian beban siklik kepada benda uji dilakukan dengan siklus tolak tarik yang bervariasi yaitu 2,5 ton; 5 ton; 7,5 ton dan monotonik sehingga benda uji balok kolom hancur. Besarnya perpindahan lateral, pola retak yang terjadi, daktilitas pada benda uji, penurunan kekakuan, disipasi energi, serta kapasitas beban maksimum benda uji dapat dianalisa dari hasil pembacaan LVDT setelah dilakukan seluruh siklus pembebanan. 


\section{Hasil dan Pembahasan}

\subsection{Beban Siklik}

Menurut (Popov, 1979), akibat beban siklik (bolak balik) yang terus menerus akan terjadi penurunan kapasitas daya tekan batang yang bisa mencapai $50 \%$ dari kapasitas awalnya bahkan hanya dengan sebuah beban siklik kuat saja. Beban siklik maksimum yang dicapai oleh benda uji joint balok kolom PBI 1971 adalah sebesar 7,47 ton pada beban tekan yang terjadi pada displacement $24 \mathrm{~mm}$ dan beban Tarik sebesar 5,19 ton pada displacement $24 \mathrm{~mm}$. Pemberian beban siklik yang dilakukan dengan beban 2,5 ton; 5 ton; 7,5 ton dan monotonik. Benda uji memiliki pola retak membentuk silang (Huruf X) pada bagian joint.

Pada saat beban siklus awal yaitu pada siklus pembebanan 2,5 ton, benda uji belum mengalami keretakan dengan joint balok kolom masih bisa menahan beban yang timbul. Retak awal mulai terjadi pada benda uji joint balok kolom pada beban tarik dimana beban yang keluar yaitu sebesar 2,5 tf, adapun retak yang terjadi terletak pada sudut joint balok kolom melintang dengan balok. Pada saat pemberian beban siklus selanjutnya untuk beban tekan, retak kembali terjadi dengan beban 2,55 tf, dengan bentuk retakan dari sudut seberangnya joint melintang balok sepanjang $7 \mathrm{~cm}$.

Tabel 1. Hasil uji pembebanan siklik benda uji PBI 1971

\begin{tabular}{|c|c|c|c|c|c|c|c|}
\hline \multicolumn{4}{|c|}{ Beban Tekan } & \multicolumn{4}{|c|}{ Beban Tarik } \\
\hline$P(t f)$ & d (mm) & $P(t f)$ & d (mm) & $P(t f)$ & d (mm) & $P(t f)$ & d (mm) \\
\hline$-0,235$ & $-1,950$ & 5,025 & 11,390 & $-1,910$ & 3,000 & $-4,824$ & $-18,6$ \\
\hline$-0,737$ & 3,990 & 5,360 & 11,660 & $-2,647$ & 0,590 & $-4,824$ & $-18,79$ \\
\hline$-0,838$ & 4,920 & 5,360 & 11,730 & $-2,546$ & 0,550 & $-4,858$ & $-18,98$ \\
\hline 1,139 & 6,110 & 5,461 & 11,800 & $-2,814$ & $-0,280$ & $-4,791$ & $-19,39$ \\
\hline 1,441 & 6,920 & 5,796 & 12,100 & $-2,781$ & $-0,330$ & $-4,757$ & $-19,4$ \\
\hline 1,407 & 6,950 & 5,729 & 12,130 & $-2,881$ & $-0,760$ & $-4,925$ & $-19,96$ \\
\hline 1,541 & 7,220 & 6,097 & 12,420 & $-2,881$ & $-1,000$ & $-4,891$ & $-20,18$ \\
\hline 1,575 & 7,350 & 6,030 & 12,510 & $-2,948$ & $-1,390$ & $-4,925$ & $-20,39$ \\
\hline 1,675 & 7,440 & 6,265 & 12,710 & $-3,015$ & $-1,840$ & $-4,958$ & $-20,64$ \\
\hline 1,809 & 7,700 & 6,298 & 12,890 & $-3,049$ & $-1,960$ & $-4,992$ & $-20,9$ \\
\hline 1,776 & 7,710 & 6,466 & 13,050 & $-3,082$ & $-2,270$ & $-5,059$ & $-21,14$ \\
\hline 2,010 & 8,020 & 6,533 & 13,240 & $-3,183$ & $-2,730$ & $-5,092$ & $-21,35$ \\
\hline 2,010 & 8,070 & 6,633 & 13,350 & $-3,283$ & $-3,090$ & $-5,025$ & $-21,48$ \\
\hline 2,178 & 8,320 & 6,801 & 13,600 & $-3,183$ & $-2,730$ & $-5,126$ & $-22,15$ \\
\hline 2,245 & 8,410 & 6,868 & 13,700 & $-3,283$ & $-3,090$ & $-5,193$ & $-22,39$ \\
\hline 2,446 & 8,580 & 6,968 & 14,010 & $-3,317$ & $-3,460$ & $-5,159$ & $-22,54$ \\
\hline 2,546 & 8,710 & 6,265 & 14,650 & $-3,384$ & $-3,830$ & $-5,092$ & $-22,68$ \\
\hline 2,613 & 8,790 & 6,198 & 14,980 & $-3,484$ & $-4,180$ & $-5,126$ & $-22,91$ \\
\hline 2,781 & 9,020 & 6,298 & 15,150 & $-3,518$ & $-4,450$ & $-5,159$ & $-23,15$ \\
\hline 2,848 & 9,070 & 6,332 & 15,500 & $-3,551$ & $-4,720$ & $-5,159$ & $-23,65$ \\
\hline \multicolumn{4}{|c|}{ Beban Tekan } & \multicolumn{4}{|c|}{ Beban Tarik } \\
\hline$P$ (tf) & d (mm) & $P$ (tf) & $\mathrm{d}(\mathrm{mm})$ & $P(t f)$ & d (mm) & $P(t f)$ & d (mm) \\
\hline 3,082 & 9,320 & 6,432 & 15,660 & $-3,585$ & $-4,790$ & $-5,193$ & $-23,89$ \\
\hline 3,116 & 9,380 & 6,466 & 16,040 & $-3,652$ & $-5,060$ & $-5,193$ & $-24,07$ \\
\hline 3,317 & 9,590 & 6,533 & 16,190 & $-3,685$ & $-5,160$ & $-5,092$ & $-24,18$ \\
\hline 3,417 & 9,700 & 6,600 & 16,590 & $-3,752$ & $-5,640$ & $-5,059$ & $-24,42$ \\
\hline 3,551 & 9,840 & 6,734 & 17,020 & $-3,853$ & $-5,910$ & $-5,092$ & $-24,67$ \\
\hline 3,518 & 9,850 & 6,834 & 17,410 & $-3,886$ & $-6,210$ & $-5,126$ & $-24,92$ \\
\hline 3,652 & 9,970 & 6,968 & 17,830 & $-4,322$ & $-7,470$ & $-5,193$ & $-25,17$ \\
\hline
\end{tabular}




\begin{tabular}{|c|c|c|c|c|c|c|c|}
\hline 3,786 & 10,100 & 7,035 & 18,210 & $-4,054$ & $-7,790$ & $-5,226$ & $-25,4$ \\
\hline 3,920 & 10,220 & 7,102 & 18,590 & $-3,618$ & $-8,010$ & $-5,126$ & $-25,45$ \\
\hline 4,054 & 10,380 & 7,169 & 19,110 & $-3,585$ & $-8,585$ & $-5,059$ & $-25,46$ \\
\hline 4,020 & 10,390 & 7,169 & 19,110 & $-3,618$ & $-8,290$ & $-5,025$ & $-25,46$ \\
\hline 4,322 & 10,610 & 7,102 & 19,550 & $-3,819$ & $-9,130$ & $-5,126$ & $-25,61$ \\
\hline 4,288 & 10,620 & 7,203 & 19,980 & $-3,920$ & $-9,430$ & $-5,159$ & $-25,8$ \\
\hline 4,422 & 10,720 & 7,270 & 20,350 & $-3,953$ & $-9,750$ & $-5,193$ & $-25,96$ \\
\hline 4,523 & 10,840 & 7,404 & 20,700 & $-3,953$ & $-10,030$ & $-5,193$ & $-26,18$ \\
\hline 4,489 & 10,860 & 7,404 & 20,980 & $-3,987$ & $-10,640$ & $-5,226$ & $-26,75$ \\
\hline 4,757 & 11,060 & 7,303 & 21,210 & $-4,087$ & $-11,010$ & $-5,19$ & $-26,93$ \\
\hline 4,724 & 11,100 & 7,337 & 21,650 & $-4,020$ & $-11,290$ & $-5,226$ & $-27,14$ \\
\hline 4,824 & 11,180 & 7,404 & 22,070 & $-4,087$ & $-11,700$ & $-5,226$ & $-27,39$ \\
\hline \multirow[t]{16}{*}{5,059} & 11,370 & 7,471 & 22,430 & $-4,121$ & $-12,000$ & $-5,327$ & $-27,71$ \\
\hline & & & & $-4,154$ & $-12,280$ & $-5,26$ & $-27,96$ \\
\hline & & & & $-4,087$ & $-12,154$ & $-5,226$ & $-28,21$ \\
\hline & & & & $-3,886$ & $-12,64$ & $-5,226$ & $-28,48$ \\
\hline & & & & $-3,786$ & $-12,59$ & $-5,26$ & $-28,84$ \\
\hline & & & & $-4,322$ & $-15,6$ & $-5,327$ & $-29,9$ \\
\hline & & & & $-4,355$ & $-15,95$ & $-5,327$ & $-30,2$ \\
\hline & & & & $-4,456$ & $-16,31$ & $-5,193$ & $-30,23$ \\
\hline & & & & $-4,489$ & $-16,61$ & $-5,126$ & $-30,24$ \\
\hline & & & & $-4,556$ & $-16,91$ & $-5,092$ & $-30,25$ \\
\hline & & & & $-4,59$ & $-17,19$ & $-5,193$ & $-30,52$ \\
\hline & & & & $-4,657$ & $-17,44$ & $-5,226$ & $-30,81$ \\
\hline & & & & $-4,69$ & $-17,71$ & $-5,26$ & $-31,7$ \\
\hline & & & & $-4,657$ & $-17,88$ & $-5,293$ & -32 \\
\hline & & & & $-4,724$ & $-18,11$ & $-5,293$ & $-32,3$ \\
\hline & & & & $-4,757$ & $-18,4$ & $-5,293$ & $-32,58$ \\
\hline
\end{tabular}

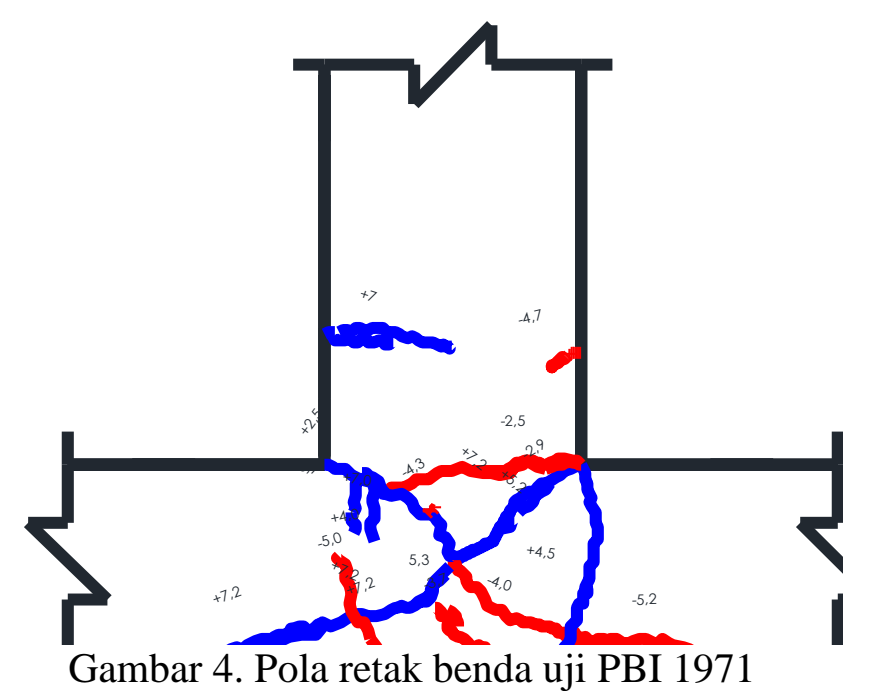

Selanjutnya pada pembebanan 5 ton untuk beban tarik, retak pertama yang terjadi adalah pada daerah sudut kanan atas joint melintang kolom pada beban 2,9 ton, sampai dengan beban maksimum siklus pada 4,96 ton. Pada beban tekan di siklus ini, retak pertama yang terjadi adalah pada daerah sudut kiri atas joint melintang kolom pada beban 3,7 tf dengan panjang retakan mencapai $12 \mathrm{~cm}$. Pada beban 7,5 ton untuk beban tekan, retak terus melebar sampai ke ujung kiri bawah kolom dengan beban yang terjadi mencapai beban maksimum sebesar 7,47 ton 
dengan displacement $24 \mathrm{~mm}$. Pada displacement $24 \mathrm{~mm}$ untuk pembebanan siklus ini juga, beban tarik mencapai beban sebesar 5,19 tf dengan pola retak mengikuti pola dari beban tarik sebelumnya. Untuk pembebanan monotonik, retak tetap terjadi pada daerah sekitaran joint balok kolom, sampai beban maksimum siklus yaitu sebesar 5,32 tf dengan displacement 32,55 $\mathrm{mm}$.

Selain daripada hasil pembebanan yang dapat dilihat pada pembacaan LVDT, dapat juga dilihat pola retak yang muncul pada permukaan benda uji. Ragam pola retak yang terjadi pada benda uji selama pembebanan dapat dilihat lebih jelas pada gambar berikut.

\subsection{Kapasitas Benda Uji}

Titik tertinggi dari envelope grafik hubungan beban dan perpindahan, didapatkan kapasitas kekuatan maksimum benda uji balok kolom. Untuk benda uji PBI 1971 didapatkan sebesar 7,47 tf (tekan) dan 5,19 tf (Tarik).

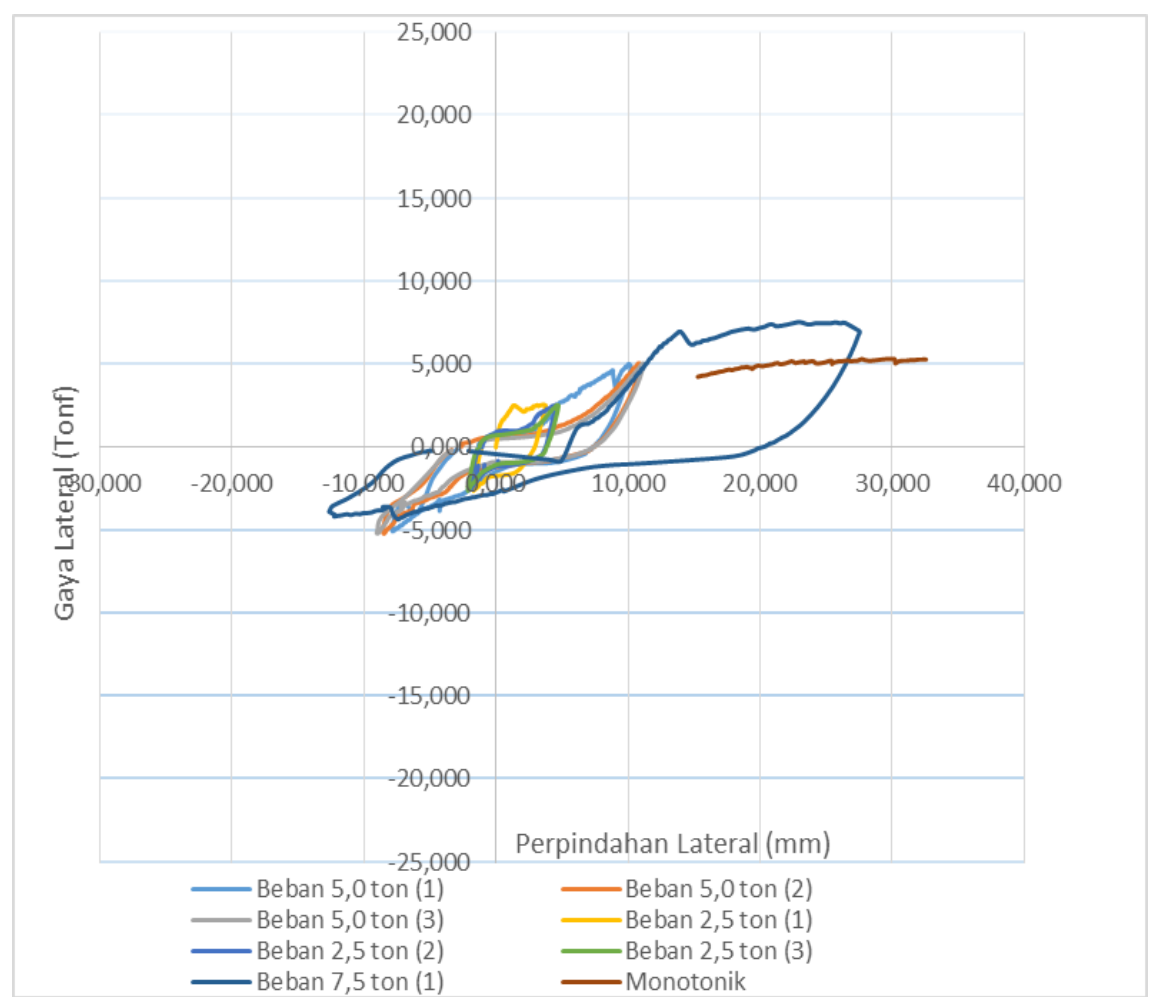

Gambar 5. Kurva histeritik perilaku struktur terhadap beban siklik

Pada grafik dibawah diperlihatkan bahwa beban terus bertambah seiring dengan bertambahnya displacement. Saat kondisi maksimum terjadi kehancuran patah dan retak pada daerah joint yang mengakibat beban berkurang selama bertambahnya displacement.

\subsection{Penurunan Kekakuan, Disipasi Energi, dan Daktilitas Struktur}

Berdasarkan data hasil pengujian dan hasil perhitungan tersebut, benda uji PBI 1971 mengalami penurunan kekakuan dimulai dari perpindahan lateral 1,74 mm sampai pada perpindahan $24,04 \mathrm{~mm}$ sebesar $0,318 \mathrm{~mm}$. 
Tabel 2. Penurunan kekakuan secant benda uji PBI 1971

\begin{tabular}{|c|c|c|c|c|c|c|c|c|}
\hline Beban & $\begin{array}{l}\mathrm{H}+ \\
(\mathrm{tf})\end{array}$ & $\frac{\mathrm{d}+}{(\mathrm{mm})}$ & $\begin{array}{l}\mathrm{H}- \\
\text { (tf) }\end{array}$ & $\frac{\mathrm{d}-}{(\mathrm{mm})}$ & $\begin{array}{l}\text { Kekakuan } \\
\text { per Siklus }\end{array}$ & $\begin{array}{c}\text { Rerata } \\
\text { Kekakuan }\end{array}$ & $\begin{array}{c}\text { Rerata } \\
\text { Penurunan }\end{array}$ & $\begin{array}{c}\text { Rerata } \\
\text { Perpindahan }\end{array}$ \\
\hline \multirow{3}{*}{2,5} & 2,58 & 3,76 & $-2,61$ & $-1,74$ & 0,944182 & \multirow{3}{*}{0,825} & \multirow{3}{*}{1} & \multirow{3}{*}{4,35} \\
\hline & 2,58 & 4,56 & $-2,54$ & $-1,99$ & 0,782595 & & & \\
\hline & 2,546 & 4,73 & $-2,61$ & $-2,14$ & 0,750946 & & & \\
\hline \multirow{3}{*}{5} & 5,025 & 10,25 & $-5,05$ & $-7,91$ & 0,555286 & \multirow{3}{*}{0,528} & \multirow{3}{*}{0,639} & \multirow{3}{*}{10,803} \\
\hline & 5,059 & 10,96 & $-5,19$ & $-8,59$ & 0,524399 & & & \\
\hline & 5,059 & 11,2 & $-5,15$ & $-9,05$ & 0,504593 & & & \\
\hline 7,5 & 7,538 & 27,56 & $-4,32$ & $-12,6$ & 0,295025 & 0,295 & 0,357 & 27,56 \\
\hline
\end{tabular}

Berdasarkan data yang dihasilkan, nilai energi disipasi pada pembebanan tekan pada tiap siklus berbeda. Energi disipasi yang didapatkan semakin besar seiring penambahan jumlah siklus. Ini berarti sesuai dengan hubungan energi dan beban tarik lateral.

Tabel 3. Hubungan energi disipasi dan beban pada benda uji PBI 1971

\begin{tabular}{|c|c|c|c|c|c|c|c|c|c|c|}
\hline \multirow[b]{2}{*}{ No } & \multirow[b]{2}{*}{ Beban } & \multirow[b]{2}{*}{ Siklus } & \multicolumn{2}{|c|}{ Energi Input } & \multicolumn{2}{|c|}{ Energi Disipasi } & \multirow[b]{2}{*}{$\begin{array}{l}\text { energi input } \\
\text { dan disipasi } \\
(+)\end{array}$} & \multirow[b]{2}{*}{$\begin{array}{c}\text { energi input } \\
\text { dan disipasi } \\
(-)\end{array}$} & \multirow{2}{*}{$\begin{array}{c}\text { Energi } \\
\text { Input } \\
\text { Total (+) }\end{array}$} & \multirow{2}{*}{$\begin{array}{c}\text { Energi } \\
\text { Input } \\
\text { Total } \\
(-)\end{array}$} \\
\hline & & & $(+)$ & $(-)$ & $(+)$ & $(-)$ & & & & \\
\hline & 0 & 0 & 0.00 & 0.00 & 0.00 & 0.00 & 0.00 & 0 & 0 & 0 \\
\hline 1 & 2.50 & 3 & 0.07 & 0.06 & 1.32 & 1.01 & 0.05 & 0.06 & 1.38 & 1.07 \\
\hline 2 & 5.00 & 3 & 0.64 & 1.28 & 2.85 & 3.25 & 0.22 & 0.39 & 3.49 & 4.53 \\
\hline 3 & 7.00 & 1 & 1.51 & 1.60 & 10.96 & 6.27 & 0.14 & 0.26 & 12.46 & 7.87 \\
\hline
\end{tabular}

Sedangkan untuk daktilitas struktur, perpindahan ultimit (du) didapatkan sebesar 26,06 mm. Nilai perpindahan leleh (dy) berdasarkan grafik envelope beban dan perpindahan adalah sebesar 12,07 mm. Maka nilai daktilitas struktur yang dihasilkan sesuai persamaan (3) adalah 2,16.

\section{Kesimpulan dan Saran}

\subsection{Kesimpulan}

Berdasarkan hasil penelitian yang dilakukan, dapat diambil kesimpulan bahwa dengan tidak adanya penyaluran tulangan dan tulangan sengkang pada joint balok kolom sesuai PBI 1971, kapasitas beban siklik maksimum yang didapatkan oleh benda uji pada displacement $24 \mathrm{~mm}$ adalah sebesar 7,47 tf (tekan) dan 5,19 tf (tarik) dengan displacement maksimum yang dapat diperoleh pada saat pembebanan monotonic adalah sebesar $32,58 \mathrm{~mm}$.

\subsection{Saran}

Penelitian selanjutnya disarankan dengan cara memperbaiki benda uji yang sudah hancur. Penelitian ini akan sangat bermanfaat karena sebagian bangunan yang sudah terbangun di lapangan masih menggunakan standar PBI 1971 dimana pada bagian sambungan (joint) tidak diberikan tulangan geser. 


\section{Daftar Kepustakaan}

Dipohusodo, I. (1994) Struktur Beton Bertulang. Jakarta: PT. Gramedia Pustaka Utama.

Nawy, T. (1998) Beton Bertulang: Suatu Pendekatan Dasar, Terjemahan

Bambang Suryoatmono. Bandung: Refika Aditama.

PBI 1971 (1971) Peraturan Beton Bertulang Indonesia. Bandung: Yayasan Lembaga Penyelidikan Masalah Bangunan.

Popov, E. (1979) Cyclic Inelastic buckling of thin tubular columns. California.

Sudarmoko (1996) Bertulang, Perencanaan dan Analisis Kolom Beton.

Yogyakarta: Biro Penerbit.

Timoshenko (1986) Teori Elastisitas, Terjemahan Darwin Sebayang. Jakarta: Erlangga. 